\title{
Kedilerde felid alphaherpesvirus 1 (FeHV-1)'in moleküler tanısı ve asemptomatik kedilerin enfeksiyonun epidemiyolojisindeki rolünün belirlenmesi
}

\author{
Yakup Yıldırım¹, Seval Bilge-Dağalp², Fırat Doğan³ , Ali Küçük ${ }^{4}$, Gülizar Acar ${ }^{5}$, Ramazan Yıldız ${ }^{6}$, Mehmet Kale \\ Sibel Hasırcıoğlu ${ }^{1}$, Kamil Atlı ${ }^{1}$, Hasbi Sait Saltık ${ }^{1}$ \\ ${ }^{1}$ Viroloji Anabilim Dalı, Veteriner Fakültesi, Burdur Mehmet Akif Ersoy Üniversitesi, Burdur/Türkiye \\ ${ }^{2}$ Viroloji Anabilim Dalı, Veteriner Fakültesi, Ankara Üniversitesi, Ankara/Türkiye \\ ${ }^{3}$ Viroloji Anabilim Dalı, Veteriner Fakültesi, Mustafa Kemal Üniversitesi, Hatay/Türkiye \\ ${ }^{4}$ Hayvan Hastanesi, Veteriner Fakültesi, Burdur Mehmet Akif Ersoy Üniversitesi, Burdur/Türkiye \\ ${ }^{5}$ Viroloji Anabilim Dalı, Veteriner Fakültesi, Atatürk Üniversitesi, Erzurum/Türkiye \\ ${ }^{6}$ İç Hastalıkları Anabilim Dalı, Veteriner Fakültesi, Burdur Mehmet Akif Ersoy Üniversitesi, Burdur/Türkiye
}

Anahtar Kelimeler: felid alphaherpesvirus 1

filogeni

kedi

PCR

\begin{abstract}
Key Words:
felid alphaherpesvirus 1

PCR
\end{abstract}

phylogeny

Geliș Tarihi : : 12.10 .2021

Kabul Tarihi : 25.12.2021

Yayın Tarihi : 29.04.2022

Makale Kodu : 1008528

Sorumlu Yazar:

Y. YILDIRIM

(yyildirim@mehmetakif.edu.tr)

ORCID

Y. YILDIRIM $0000-0003-4299-4712$

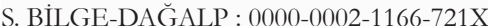

F. DOĞAN :0000-0001-8656-3645

A. KÜÇÜK :0000-0001-9929-1378

G. ACAR :0000-0002-0800-1564

R. YILDIZ :0000-0001-5772-0891

M. KALE :0000-0003-4156-1077

S. HASIRCIOĞLU : :0000-0002-5436-0795

K. ATLI :0000-0002-2266-4372

HS. SALTIK : :0000-0002-3283-7062

\section{ÖZ}

Kedilerin solunum sisteminin en yaygin patojenlerinden biri olan Felid alphaherpesvirus 1 (FeHV-1) çoğunlukla ateş, mukopurulent nazal akıntı, konjunktivitis, iştahsızlık gibi semptomlarla seyretmekte ve özellikle yavru kedilerde alt solunum sistemi enfeksiyonları sonrasında ölümlere neden olabilmektedir. Enfeksiyon akut ve subklinik enfekte kedilerin üst solunum yolu sekret ve ekskretleri yoluyla bulaşır. Bu çalışmada hem klinik semptom göstermeyen hem de solunum sistemi enfeksiyonu semptomları gösteren, 6 ay-8 yaş arasında, sahipli veya sahipsiz, farklı ırklara ait 55 dişi, 57 erkek olmak üzere toplamda 112 kediden alınan EDTA’lı kan örneklerinde PCR tekniği ile FeHV-1 nükleik asit varlı̆̆1 araştırılmış ve pozitif bulunan örneklerin dizin analizi gerçekleştirilerek filogenetik ağaç oluşturuldu. Yapılan PCR testi sonucunda örneklerin \%33.93'ünde (38/112) FeHV-1 nükleik asidi tespit edildi. Klinik semptom göstermeyen kedilerde pozitiflik oranı \%20.83 (5/24) iken, klinik semptom gösteren kedilerde bu oran \%37.50 (33/88) olarak belirlendi ve bu verilere dayanarak solunum sistemi semptomu gösteren kediler kadar semptom göstermeyen kedilerin de enfeksiyonun epidemiyolojisinde rolünün olduğu kanaatine varıldı. Ayrıca örneklenen kedilerde yaş ve cinsiyete göre pozitiflik oranları arasında anlamlı bir farkın olmadığı ancak özellikle 1 yaş altındaki kedilerde enfeksiyon oranının nispeten daha yüksek olduğu tespit edildi.

Molecular diagnosis of Felid Alphaherpesvirus 1 (FeHV-1) in cats and detecting the role of asymptomatic cats in the epidemiology of the infection

\section{ABSTRACT}

Felid Alphaherpesvirus 1 (FeHV-1), one of the most common pathogens of cat respiratory system, mostly proceeds with symptoms such as fever, mucopurulent nasal flow, conjunctivitis and loss of appetite and might cause death especially in kittens following lower respiratory system infections. Transmission of the infection occurs via upper respiratory tract secret and excreta of acute and subclinically infected cats. In this study, FeHV-1 nucleic acid presence was searched using PCR technique in blood samples with EDTA taken from 112 cats, 55 females and 57 males, from different races, owned or stray, between 6 months -8 years of age, either didn't show clinical symptoms or showing clinical symptoms of respiratory system infection and phylogenetic tree was created by carrying out index analysis of positive samples. As a result of the PCR test, FeHV-1 nucleic acid was detected in $33.93 \%(38 / 112)$ of the samples. The positivity rate was $20.83 \%$ (5 / 24) in cats without clinical symptoms while it was 37.50\% (33 / 88) in cats with clinical symptoms. Based on these data, it was concluded that cats showing respiratory system symptoms as well as non-symptomatic cats have a role in the epidemiology of the infection. In addition, it was determined that there was no significant difference between the positivity rates according to age and gender in the cats sampled, but the infection rate was relatively higher, especially in cats under 1 year old.

\section{GİRIŞ}

Solunum sistemi problemli kedilerde yaygın olarak görülen FeHV-1 (Felide Alphaherpesvirus1) Herpesviridae familyas1, Alphaherpesvirinae altfamilyas1, Varicellovirus genusunda yer alan ve dsDNA içeren zarflı bir virustur $(1,2,3)$. Etken genel olarak nazal, oküler, oral sekret ve ekskretler yoluyla saç1lmaktadır. Indirekt bulaşmada ise kontamine alet, mama ve su kapları gibi fomitler rol oynar $(4,5)$. FeHV-1 her yaștan, 1rktan veya cinsiyetten kedide enfeksiyon meydana getirsede, şiddetli semptomlar genellikle 6 aydan küçük hayvanlarda görülmektedir (2). Çoğunlukla üst solunum yolu epitellerinde ve konjunktivada replike olan virusun inkubasyon süresi 2-6 gün sürer. Göz ve üst solunum yolu enfeksiyonlarina neden olan etken kedilerde konjunktivitise neden olan en önemli patojendir (5). Klinik olarak rhinitis, rhinotracheitis ve sinüzitise neden olur, bunun- 
la birlikte herpetik enfeksiyonların patognomik lezyonlarından biri olarak görülen dentrik ülserasyonlar ve stromal keratitisler de meydana getirir $(6,7)$.

FeHV-1 diğer Alphaherpesviruslarda olduğu gibi primer enfeksiyonu takiben nöronların trigeminal ganglionlarında yaşam boyu latent kalabilir (7). Latent enfekte kediler etkenin taşınmasında ve saçılmasında önemli bir rol oynar (2). Enfeksiyonun tanisinda direkt immunfluoresan ve polimeraz zincir reaksiyon (Polymerase Chain Reaction (PCR)) tekniği yaygin olarak kullanılmaktadır (8).

Bu bilgiler 1şı̆̆1nda planlanan bu araştırmada, FeHV-1 enfeksiyonu şüpheli ve/veya sağlıklı görünümlü ve söz konusu etkene karşı aşılanmamış kedilerde enfeksiyonun varlı̆̆ının moleküler metotlarla tespiti ve sağlıklı görünümlü (asemptomatik) kedilerin enfeksiyonun epidemiyolojisindeki rolünün irdelenmesi amaçlanmıştır. Ayrıca yaş, cinsiyet, sahipli/sahipsiz ve klinik bulgu gibi parametrelerin de enfeksiyonun prevalans1na etkisi incelenmiştir.

\section{GEREÇ ve YÖNTEM}

\section{Örneklenen Hayvanlar}

Araştırmada sağlıklı görünümlü ile konjuktivitis, rhinitis, nazal-okuler akıntı gibi solunum yolu enfeksiyonu bulguları gösteren ve söz konusu enfeksiyona karşı aşılanmamış 6 ay- 8 yaş aras1, farklı 1rklarda 55 dişi, 57 erkek olmak üzere toplam 112 kediden etilendiamin tetraasetik asit (EDTA) içeren tüplere kan örnekleri topland.

Daha sonra kan örnekleri 1200 rpm'de 10 dakika süreyle santrifüj edildi. Ayrılan lökosit tabakası steril pastör pipeti yardımıyla içerisinde phosphate-buffered saline (PBS) (VWR, ABD) bulunan $2 \mathrm{ml}$ hacminde steril tüplere aktarıldı ve 2000 rpm'de 10 dakika $4{ }^{\circ} \mathrm{C}$ 'de santrifüj edildi. Tüpün dibinde kalan lökosit tabakası toplanarak üzerine PBS eklendi ve 2000 rpm'de 10 dakika $4{ }^{\circ} \mathrm{C}$ 'de tekrar santrifüj edildi. Yıkama işlemi son bir kez tekrar edildikten sonra dipte kalan lökosit peleti üzerine 1 $\mathrm{ml}$ antibiyotikli PBS eklendi ve test aşamasına kadar $-80{ }^{\circ} \mathrm{C}$ de derin dondurucuda sakland.

\section{Polymerase Chain Reaction (PCR)}

Viral nükleik asit ekstraksiyonu Sambrook'un (9) bildirdiği yönteme uygun olarak gerçekleştirildi. Ekstrakte edilen viral DNA'nın amplifikasyonu amaciyla Nunberg ve ark. (10) bildirmiş olduğu timidin kinazı (TK) kodlayan gen bölgesine spesifik primer çiftleri kullanıldı. PCR prosedüründe bir örnek için reaksiyon hacmi, $3 \mu \mathrm{l}$ (50 ng) hedef DNA, 0,5 $\mu \mathrm{l}$ Taq DNA polimeraz (Thermo Scientific Cat No: EP0402), 3,5 mM dNTP, primerlerin her birinden $10 \mathrm{pmol}, 1.5 \mathrm{mM} \mathrm{MgCl}_{2}$ ve $10 \mathrm{x}$ PCR buffer eklenerek toplamda $30 \mu$ l' ye tamamland1. Is 1 döngüleri ise $95^{\circ} \mathrm{C}$ de $5 \mathrm{dk}$ ön denaturasyon aşamasından hemen sonra 35 döngü $95^{\circ} \mathrm{C}$ de 30 sn denaturasyon, $56^{\circ} \mathrm{C}$ de 45 sn annealing ve $72^{\circ} \mathrm{C}$ de $1 \mathrm{dk}$ extension aşamaları olacak şekilde düzenlendi. Elde edilen 287 bp büyüklüğündeki amplikonlar \%1' lik agaroz jel'de elektroforez işlemine tabi tutularak UV ışığı altında görüntülendi. Çalışmada pozitif kontrol olarak Ankara Üniversitesi Veteriner Fakültesi Viroloji ABD stoklarında bulunan referens FeHV-1 suşu kullanılırken, negatif kontrol olarak steril distile su kullanıldı.

\section{Dizin Analizi}

PCR aşamasında FeHV-1 nükleik asiti tespit edilen ve ürün kalitesi iyi olan 11 örneğe kısmi dizin analizi yapıldı. Çalışmada elde edilen dizinler, Genbankası veri tabanında bulunan diğer FeHV-1 suşları ile karşılaştırıldı. Filogenetik ağaç; Maximum Likelihood (ML) yöntemi ve Tamura 3-parametreleri ile MEGA-X (Molecular Evolutionary Genetics Analysis software) programının en son sürümü kullanılarak oluşturuldu. Bütün metotlarda 1000’lik ön yükleme değeri tekrarlandı ve filogenetik ağaç için en iyi ikame modeli seçildi.

\section{BULGULAR}

Kontrol edilen örneklerin \%33.93'ünde (38/112) FeHV-1 viral nükleik asit varlığ1 tespit edildi. Solunum sistemi enfeksiyonu bulguları gösteren kedilerde pozitiflik oran1 \%37.50 (33/88), sağlıklı görünümlü kedilerde pozitiflik oranı \%20.83 (5/24) olarak belirlendi. Pozitiflik oranları 1 yaş altındaki kediler için \%53.33 (8/15), 1-3 yaş arasındakiler için \%51.51 (23/73), 4-5 yaş arasındakilerde $\% 23.53(4 / 17)$ ve 5 yaş üzerindekiler için ise \%42.86 (3/7) olarak bulundu. FeHV-1 yönünden pozitif olarak tespit edilen kedilerin \%30.91'inin (17/38) dişi, \%36.84' ünün (21/38) erkek olduğu belirlendi (Tablo 1). Klinik bulgular açısından özellikle konjunktivitis ve rinitis semptomlu kedilerde FeHV-1 görülme oranı diğer bulgulara göre daha yüksek bulunmuştur (Tablo 2). Aynı şekilde klinik semptom gösteren 1 yaş altı kedilerde enfeksiyonun seyrinin daha şiddetli olduğu gözlemlenmiştir.

Yap1lan istatistiksel analiz sonrasinda, numunelerin toplandığ1 sahipli ve sahipsiz hayvanlarda tespit edilen FeHV-1 pozitiflik değerlerindeki farklılı̆̆ın istatistiki açıdan önemsiz $(P>0.05)$ olduğu tespit edildi $(\chi 2=0.690, P=0.406)$. Klinik semptom gösteren kediler ile sağlıklı görünümlü kedilerde tespit edilen pozitiflik oranlarındaki farklılık istatistiki açıdan anlamsiz $(P>0.05)$ olarak bulundu $(\chi 2=2.337, P=0.126)$. Yine erkek ve dişilerde belirlenen pozitiflik oranlarındaki farklılığın ve farklı yaş gruplarında belirlenen pozitiflik oranlarındaki farklılıkların da istatistiki açıdan önemsiz $(P>0.05)$ olduğu tespit edildi (Erkek/dişi $\chi 2=0.440, P=0.507$; yaş gruplar1 $\chi 2=3.780$, $\mathrm{P}=0.286)$.

Ayrıca ürün kalitesi iyi olan 11 kediye ait örneklerin TK geni kısmi dizin analizi sonrasında oluşturulan filogenetik ağacı Şekil 1'de verildi. Bu çalışmada pozitif olarak belirlenen izolatlarin TK gen düzeyinde birbirine ve daha önce ülkemizde tespit edilen izolatlara \%99-100 oranında benzer oldukları tespit edildi.

\section{TARTIŞMA}

FeHV-1 kedilerde üst solunum yolu enfeksiyonuna neden olan en önemli viral patojenlerden birisidir (4). Etken tek baş1na hastalık oluşturabileceği gibi Feline Calicivirus (FCV), Feline Panleukopenia virus (FPV), Chlamydophila felis, Mycoplasma spp., Bordatella bronchiseptica, Staphylococcus spp. gibi viral ve bakteriyel etkenlerle birlikte koenfeksiyon meydana getirebilir (11-15). FeHV-1'e bağlı olarak çoğunlukla bir yaşına kadar olan kedilerde akut enfeksiyon meydana gelir ve şiddetli üst solunum 
Tablo 1. FeHV-1 PCR pozitif olarak belirlenen kedilere ilişkin epidemiyolojik veriler

Table 1. Epidemiological data on cats identified as FeHV-1 PCR positive

\begin{tabular}{lccc}
\hline \multicolumn{1}{c}{ Epidemiyolojik Veriler } & Toplam & FeHV $(+)$ & FeHV $(-)$ \\
\hline Örnek Sayısı $(\boldsymbol{n})$ & 112 & $38(\% 33.93)$ & $74(\% 66.07)$ \\
\hline Yaş & & & \\
$<$ 1 yaş & 15 & $8(\% 53.33)$ & $7(\% 46.67)$ \\
1-3 yaş & 73 & $23(\% 51.51)$ & $50(\% 68.49)$ \\
4-5 yaş & 17 & $4(\% 23.53)$ & $13(\% 76.47)$ \\
\hline Cinsiyet & & & \\
\hline Dişi (†) & 55 & $17(\% 30.91)$ & $38(\% 60.09)$ \\
Erkek (す) & 57 & $21(\% 36.84)$ & $36(\% 63.16)$ \\
\hline Bakım Şekli & & & \\
\hline Sahipli & 65 & $20(\% 30.77)$ & $45(\% 63.23)$ \\
Sahipsiz & 47 & $18(\% 38.30)$ & $29(\% 61.70)$ \\
\hline
\end{tabular}

Tablo 2. Klinik bulgu gösteren kedilerde başlıca görülen semptomlar ve PCR sonuçları

Table 2. Main symptoms and PCR results in cats with clinical signs

\begin{tabular}{lccc}
\hline $\begin{array}{l}\text { Görülen } \\
\text { Klinik Semptom }\end{array}$ & $\begin{array}{c}\text { Klinik Semptom } \\
\text { Gösteren } \\
\text { Kedi Sayısı }\end{array}$ & $\mathbf{F H e V - 1}$ & FHeV-1 \\
& 88 & $33(\%)$ & \\
\hline Toplam & 53 & $21(\% 37.50)$ & $55(\% 62.50)$ \\
Nasal Akıntı & 48 & $28(\% 58.33)$ & $32(\% 60.38)$ \\
Okuler Akıntı & 12 & $10(\% 83.33)$ & $20(\% 41.67)$ \\
Konjuktivitis & 10 & $8(\% 80)$ & $2(\% 20)$ \\
Rhinitis & 50 & $22(\% 44)$ & $28(\% 56)$ \\
Ateş & 12 & $3(\% 25)$ & $9(\% 75)$ \\
İshal & 17 & $10(\% 58.18)$ & $7(\% 41.18)$ \\
İştahsızlık & & & \\
\hline
\end{tabular}

sistemi semptomları görülür. Bunun yanı sıra etken, trigeminal ganglionlarda latent enfeksiyon oluşturarak asemptomatik bir tabloya neden olabilmektedir $(5,16)$.

Türkiye'de kedilerin solunum sistemi etkenlerinin araștırıld1ğ1 çalışmalar sınırlı sayıdadır (17-19). Bilge-Dağalp ve Akça (17) üst solunum yolu enfeksiyonu bulguları gösteren 11 ve sağlıklı görünümlü 41 kediden alınan trakeal swap örneklerinde direkt immunofloresan tekniğini kullanarak FeHV-1'e ait antijenik yapıları tespit etmeyi amaçlamışlar ve sonuçta semptom gösteren hayvanların \%18.1'inde (2/11) sağl1klı görünümlülerin ise \%7.3'ünde (3/41) pozitiflik belirlemişlerdir. Karapınar ve ark. (18) klinik olarak solunum sistemi enfeksiyonu semptomlan gösteren 20 Van kedisinden aldıkları oküler swap örneklerini PCR yöntemini kullanarak test etmişler ve bunların \% 045 'inde $(9 / 20)$ etkene ait nükleik asit varlı̆̆1 tespit etmişlerdir. Aynı çalışmada araştırmacılar nükleik asit tespiti yapılan kedilerin hepsinin 1 yaşın altında olduğunu bildirmişlerdir. Bilge-Dağalp ve ark (14) klinik olarak solunum sistemi enfeksiyonu bulgular1 gösteren 70 kediden aldıkları örnekleri PCR yöntemi ile FeHV1 ve FCV nükleik asit varlığ1 yönünden kontrol etmişlerdir. Örneklenen kedilerin \%45,71'i (32/70) FeHV-1' e nükleik asit varlığ1 yönünden pozitif bulunmuş ve yapılan dizin analizi sonrasında örneklerin birbirlerine \%99 üzerinde benzer oldukları ortaya konulmuştur. Bayraktar ve Y1lmaz (20) da FeHV-1' in antijenik ve moleküler olarak tespiti üzerine yaptıkları araştırmada solunum sistemi enfeksiyonu semptomları gösteren 1 yaşın üstündeki kedilerde \%43,3 (26/60) oranında pozitiflik belirlemişlerdir. Söz konusu çalışmada tespit edilen pozitifliğin ev kedileri ve sokak kedileri arasındaki dağılımı ise sırasılyla $\% 30.77(8 / 26)$ ve $\% 69.23(18 / 26)$ olarak tespit edilmiştir. Kü- 


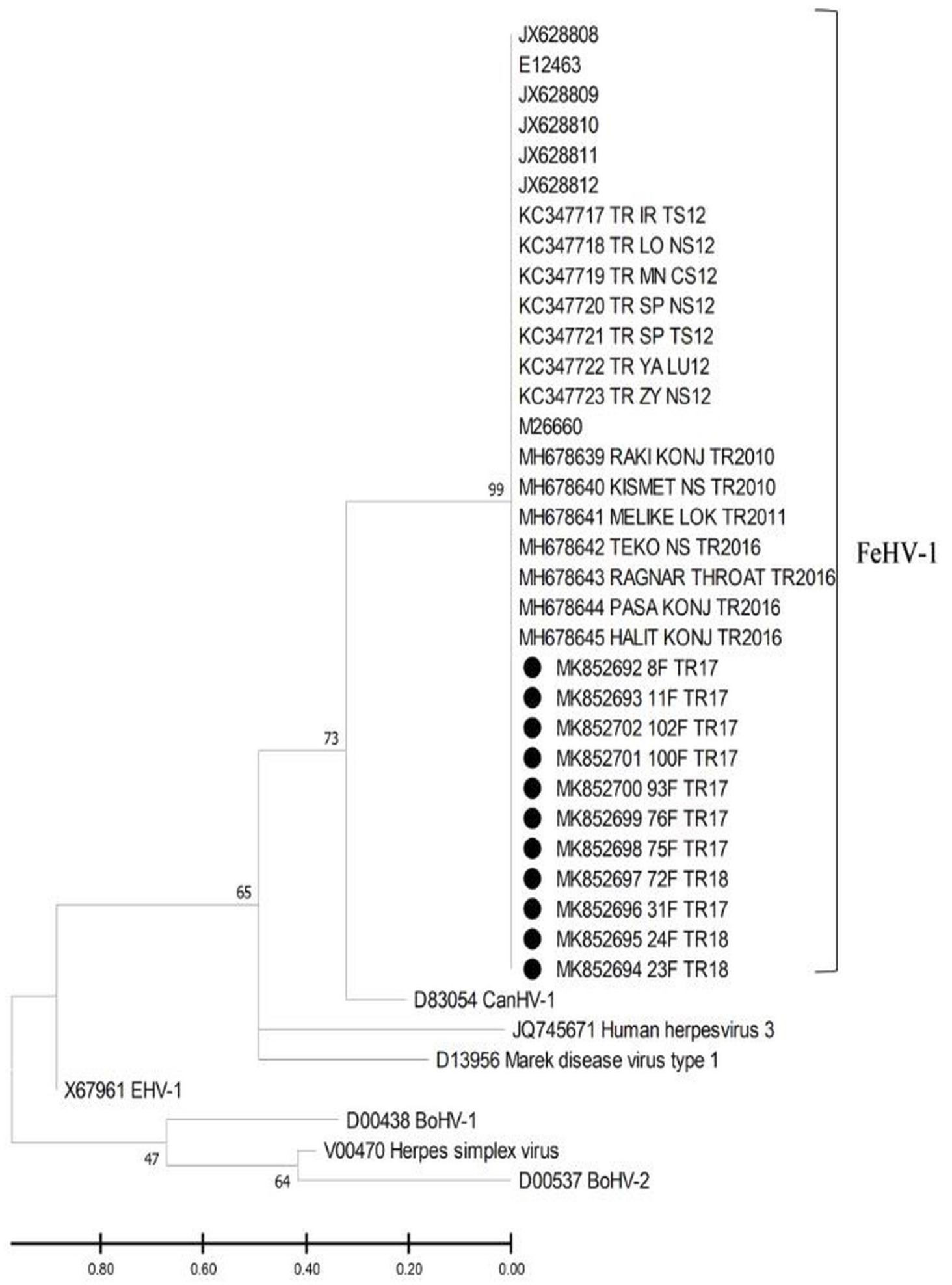

Şekil 1. FeHV-1 pozitif örneklerin TK gen sekansina ait filogenetik ağaç.

Figure 1. Phylogenetic tree of the TK gene sequence of FeHV-1 positive samples

çük ve ark. da (19) sağlıklı görünümlü ile klinik olarak solunum sistemi enfeksiyonu bulguları gösteren 75 barınak kedisinden aldıkları nazal ve oküler swap örneklerinde PCR ile FeHV-1 nükleik asit tespiti amacıyla yaptıkları çalışmada \%25.3 (19/75) oranında pozitiflik tespit etmişlerdir. Aynı çalışmada örnekleme yapilan asemptomatik hayvanlarda pozitiflik oranı $\% 16.7$ $(9 / 54)$, solunum sistemi hastalık bulguları gösteren kedilerde ise \%47.6 (10/21) olarak belirlenmiştir. Sağlıklı görünümlü olup etken tespiti yapilan kedilerin \%38.5'inin (5/9) ve solu- num sistemi enfeksiyonu klinik bulguları gösterenlerin \%40' ının (4/10) 6 aydan küçük olduğu belirtilmiştir.

Henzel ve ark. (12) asemptomatik ve solunum sistemi enfeksiyonu klinik bulguları gösteren 302 kediden aldıkları swap örneklerinde FeHV-1 pozitifliğini PCR ile \%6.95 (21/302) oranında bulmuşlardır. FeHV-1 tespit edilen kedilerin \%37,5'nin (9/21) 1 yaşın altında olduğu, \%52'sinin (13/21) semptomatik, $\% 26.7$ ' sinin (8/21) asemptomatik olduğu ve \%100' 
ünün $(21 / 21)$ başka kedilerle birlikte yaşadı̆̆ı bildirilmiştir. Baumworcel ve ark. (21) tarafindan yapılan moleküler araştırmada ise yaşları 2 ay - 1 yaş arasında değişen, aşısız sağlıklı görünümlü kediler ile konjuktivitis semptomu gösteren kedilerden alınan 108 konjuktival swap örneğinde \%57.4 oranında (62/108) FeHV-1 nükleik asit varlığını tespit etmişlerdir. Araştırmacılar, pozitif belirledikleri 21 hayvanın herhangi bir klinik semptom göstermediğini, 10 hayvanın ise konjuktivitis olduğunu bildirmişlerdir.

FeHV-1'in virolojik ve moleküler olarak tespiti üzerine yapılan araştırmalara $(19,20,22-25)$ bakıldığında, solunum sistemi klinik bulguları gösteren kedilerde prevalansının \%4.294, sağliklı görünümlü olanlarda ise \%9-63 oranları arasında olduğu görülmektedir. Bu çalışmada da elde edilen bulgular diğer araştırmacıların sonuçlarını destekler niteliktedir. Birçok araştırmada $(12,18,19,21) \mathrm{FeHV}-1$ 'in prevalansinin 6-18 ay yaş arasındaki kedilerde diğer yaş gruplarına oranla daha yüksek olduğu tespit edilmiştir. Bu bilgilere dayanarak hastalığın her yaştaki kedilerde meydana gelebileceği ancak özellikle 1 yaş altındaki kedilerde görülme olasılığının diğer yaş aralıklarına kıyasla nispeten daha yüksek olduğu sonucuna varılmıştır. $\mathrm{Bu}$ durumun nedenleri olarak maternal antikorların sağladığ1 immunitenin tamamen enfeksiyonu önleyememesi, sekonder enfeksiyonlar, aktif immünizasyonun henüz gelişmediği ve bakım-besleme koşullarının uygun olmadığı yavrularda immun sistemin baskılanmasına bağlı olarak enfeksiyonun gelişebileceği ve şiddetli klinik bulguların görülebileceği düşünülmektedir.

Daha önce yapılan birçok araştırmada $(12,19,21,24) \mathrm{FeHV}-$ 1 , akut enfekte kedilerin yanı sira asemptomatik hayvanlardan da izole edilmiştir. Bizim yaptığımız araştırmada da sözü edilen araştırmalardaki sonuçları destekleyen bulgular elde edilmiştir. Bu bulgulara göre enfeksiyonun saçllımında akut enfekte kediler kadar klinik olarak sağlıklı görünümlü kedilerin de etkin rol oynadığı sonucuna ulaşılmıştır. Persiste enfekte kediler aylarca hatta y1llarca virus taşıyıc1 olarak rol oynayabilirler (26, 27). Hayvan barınakları ve kedi otelleri gibi kedilerin yoğun olarak bir arada bulunduğu ortamlarda birçok stres faktörü olabilmektedir. Bu tür yerlerde barındırılan sağlıklı kediler için, asemptomatik FeHV-1 latent enfekte kedilerin potansiyel risk oluşturduğu unutulmamalıdır.

Daha önce konu ile ilgili yapılan araştırmalarda (12, 18, 19 , 21) FeHV-1 enfeksiyonunun rrk veya cinsiyet predispozisyonunun olmadığ1 görülmüştür. Bu çalışmada da dişi ve erkek hayvanlarda tespit edilen pozitiflik oranının istatistik açıdan önemsiz $(P>0.05)$ olduğu belirlenmiştir.

Dünya'da tespit edilen FeHV-1 suşları arasındaki yakınlıklar filogenetik çalışmalarla ortaya konulmaya çalışılmıştır. Türkiye'de Bilge-Dağalp ve ark. (14) izole ettikleri FeHV-1 saha suşlarının kısmi TK geni filogenetik analizleri sonrasinda, FeHV-1 saha viruslarının kendi aralarında ve Genbankasında yer alan diğer viruslar ile \%90 üzerinde benzer olduğunu ortaya koymuşlardır. Bu çalışmada da tespit edilen FeHV-1 saha viruslanı Genbankasında yer alan diğer viruslar ile \%90 üzerinde benzer bulunmuştur. Bu çalışmanın devamında yapilabilecek çalışmalarda virusun farklı bölgelerinin genetik karakterizasyonun yapılması, FeHV-1 saha suşlarının genetik çeşitliliğini ortaya koymak adına yararlı olabilecektir. Bu çalıșmada örneklenen kedilerden EDTA'lı kan örneği alınarak Anabilim Dalımız laboratuvarına gönderilmiştir. Solunum sistemi problemli hayvanlarda özelikle nazal, oküler, oral, orofarengeal sekret ve ekskretler tanıda çok daha değerlidir. Kan örneklerinin yanı sıra solunum sistemine ait swap örneklerinin alınması durumunda pozitiflik oranının çok daha yüksek olacağını düşünmekteyiz. Ancak lokal bir enfeksiyon olmasına rağmen kan örneklerinde yüksek pozitifliğin tespit edilmesi de ayrıca üzerinde durulması gereken bir konudur. Nitekim Bilge-Dağalp ve ark. (14) çalışmasinda da solunum sistemi problemli kedilerin kan örneklerinin \%25'i, konjunktival swap örneklerinin \%46.6's1 ve orofarengeal swap örneklerinin \%85.7'si FeHV-1 yönünden PCR ile pozitif olarak değerlendirilmiştir.

\section{SONUÇ}

Sonuç olarak FeHV-1 enfeksiyonunun epidemiyolojisinde akut enfekte kedilerin yanı sira asemptomatik kedilerin de önemli rolü olduğu bir kez daha ortaya konmuştur. Ayrıca, FeHV-1 enfeksiyonunda yaş sinırlaması olmamasına rağmen hastalığın prevalansının 1 yaşın altındaki kedilerde nispeten daha yüksek olduğu tespit edilmiştir (Tablo 1). Yapılan çalışmalarda FeHV-1' e karşı geliştirilen aşıların persiste enfekte hayvanlara karşı tam bir koruma sağlayamadıkları fakat trigeminal ganliyonlarındaki latent virus yoğunluğunu, virusun saçılım süresini ve saçılan virus miktanını azalttığı, dolayısıyla prognozu olumlu şekilde etkilediği bilinmektedir (6, 26, 27). Bundan dolayı koruyucu olarak FeHV-1'e karşı aş1 uygulamalarının yapılması yarar sağlayacaktır. FeHV-1 enfeksiyonu ile mücadelede barınak, bakımevleri ve hayvan pansiyonları gibi popülasyonun yoğun olduğu, immunsupresyona neden olan stres faktörlerini bir arada bulunduran, sürekli hayvan sirkülasyonunun olduğu ortamlarda dezenfeksiyon ve karantina uygulamalarının yapılması, bununla birlikte rutin aşılamalar yapılarak hayvanlarda immun sistemin stimule edilmesi doğru uygulamalar olacaktır. Ayrica solunum sistemi enfeksiyonuna neden olan diğer viral ve bakteriyel etkenlerin de prevalans/seroprevalans araştırmalarının yapılması ve koruyucu tedbirlerin alınması enfeksiyonların önlenmesine ve kontrol altına alınmasına katkı sağlayacaktır.

\section{BEYANNAMELER}

\section{Etik Onay1}

Bu araştırmanın yürütülmesi Burdur Mehmet Akif Ersoy Üniversitesi Hayvan Deneyleri Yerel Etik Kurulu (MAKÜ-HADYEK, Say1 No: E-93773921-020-76889) tarafindan uygun görülmüştür.

\section{Çıkar Çatışması}

Yazarlar, herhangi bir çıkar çatışması beyan etmemektedir.

\section{Yazar Katk1ları}

Fikir, Kavram ve Tasarım: YY, SBD

Veri Toplama ve Analiz: YY, SBD, FD, AK, GA, RY, MK, SH, $\mathrm{KA}$, HSS

Makalenin Yazımı: YY, AK 
Eleştirel İnceleme: YY, SBD

\section{Veri kullanılabilirliği}

Bu çalışmanın bulgularını destekleyen veriler makul talep üzerine sorumlu yazardan temin edilebilir.

\section{KAYNAKLAR}

1. Maes R. Felid Herpesvirus Type 1 Infection in Cats: A Natural HostModel for Alphaherpesvirus Pathogenesis. International Scholarly Research Network Veterinary Science. 2012; 1-14. doi:10.5402/2012/495830.7

2. Maclachlan NJ, Dubovi EJ, Barthold SW, Swayne DE, Winton JR. Fenner's Veterinary Virology. 5th ed. Elsevier Inc. San Diego: USA; 2017.

3. ICTV, 2021. Erişim Adresi: https://talk.ictvonline.org/ taxonomy/p/taxonomy-history?taxnode_id=202001453, Erişim Tarihi: 27.09.2021.

4. Thiry E, Addia D, Belak S, Boucraut-Baralon C, Egberink H, Frymus T, Jones T, Hartmann K, Hoise MJ, Llorent A, Lutz H, Marsilio F, Pennisi MG, Radford AD, Truyen U, Hornizek MC. ABCD Guidelines of prevention and management; Journal of Feline Medicine and Surgery. 2009; 11: 547-555.

5. Küçük A, Yıldırım Y. Felide Herpesvirus-1 Enfeksiyonu. Etlik Vet Mikrobiyol Derg. 2018; 29: 76-81.

6. Maggs DJ. Update on Pathogenesis, Diagnosis and Treatment of Feline Herpesvirus Type 1. Clinical Techniques in Small Animal Practice. 2005; 20: 94-101.

7. Stiles J. Ocular manifestations of feline viral diseases, The Veterinary Journal. 2014; 201: 166-173.

8. Gould D. Feline Herpesvirus-1: Oculer Manifestations, Diagnosis and Treatment Options. Journal of Feline Medicine and Surgery. 2011; 13: 333-346.

9. Sambrook J. Molecular Cloning. Cold Spring Harbor Laboratory Press. 2nd Edition. 1989.

10. Nunberg JH, Wright DK, Cole GE, Petrovskis EA, Post LE, Compton T, Gilbert JH. Identification of the thymidine kinase gene of feline herpesvirus: use of degenerate oligonucleotides in the polymerase chain reaction to isolate herpesvirus gene homologs. Journal of Virology. 1989; 63(8): 3240-3249.

11. Helps C, Reeves N, Egan K, Howard P, Harbour D. Detection of Chlamydophila felis and Feline Herpesvirus by Multiplex Real-Time PCR Assay. 2003; 41(6): 2734-2736.

12. Henzel A, Brum MCS, Lautert C, Martins M, Lovato LT, Weiblen R. Isolation and Identification of Feline Calicivirus and Feline Herpesvirus in Southern Brazil. Brazilian Journal of Microbiology. 2012; 43 (2): 560-568.

13. Fiorito F, Cantiello A, Granato GE, Navas L, Diffidenti C, De Martino L, Maharajan Vi Olivieri F, Pagnini U, Iovane G. Clinical improvement in feline herpesvirus 1 infected cats by oral lowdose of interleukin-12 plus interferon-gamma, Comparative Immunology, Microbiology and Infectious Dise- ases. 2016; 48: 41-47.

14. Dağalp SB, Doğan F, Farzani TA, Babaoğlu AR, Kırmızı GA, Çabalar M. Solunum sistemi problemli kedilerde Feline Herpesvirus 1 (FHV-1) ve Feline Calicivirus varllğının moleküler olarak araştır1lması. Eurasian J Vet Sci. 2019; 35: 131-138.

15. Liu C, Liu Y, Qian P, Cao Y, Wang J, Sun CY, Huang B, Cui N, Huo N, Wu H, Wang L, Xiangfeng X, Tian K. Molecular and serological investigation of cat viral infectious diseases in China from 2016 to 2019. Transbound Emerg Dis. 2020; 0: $1-7$.

16. Ettinger SJ, Feldman EC. Textbook of Veterinary İnternal Medicine Disease of the dog and the cat. Seventh edition. St. Louis Missouri: Saunders Elsevier. 2010; p. 946.

17. Dağalp SB, Akça Y. Detection of Feline Herpes Virus 1 from Domestic Cats With or Without Respiratory Symptoms, Indian Veterinary Journal. 2004; 81(1): 1-5.

18. Karapınar Z, Dinçer E, Ataseven VS, Karaca M. Feline herpesvirus-1 infection in Van cats with conjunctivitis. YYU Vet Fak Derg. 2014; 25 (1): 15-7.

19. Küçük A, Sağ N, Çakır C, Acar G, Yıldırım Y, Ataseven VS. Sağlıklı Görünüşlü ve Solunum Sistemi Problemli Barınak Kedilerinde Feline Herpesvirus Tip 1 (FeHV-1) Enfeksiyonu. Erciyes Üniv Vet Fak Derg. 2017; 14(1): 25-30.

20. Bayraktar E, Yilmaz H. Molecular Detection and Clinical Aspects of Feline Herpesvirus-1, Feline İmmunodeficiency Virus and Feline Leukemia Virus in Cats in Istanbul, Turkey. Pak Vet J. 2020; http://dx.doi.org/10.29261/pakvetj.

21. Baumworcel N, Soares AMB, Silva SB, Almeida NKO, De Castro TX. Correlation between clinical signs of feline conjunctivitis and molecular detection of felid Herpesvirus-1, feline Calicivirus, Chlamydophila felis and Mycoplasma felis in cats from shelters in Rio de Janeiro. Brazilian Journal of Veterinary Research and Animal Science. 2017; 54(1): 18-26.

22. Harbour DA, Howard PE, Gaskell RM. Isolation of feline calicivirus and feline herpesvirus from domestic cats 1980 to 1989. VetRec. 1991; 128: 77- 80.

23. Stiles J, McDermott M, Bigsby D, Willis M, Martin C, Roberts W, Greene C. Use of nested polymerase chain reaction to identify feline herpesvirus in ocular tissue from clinically normal cats and cats with corneal sequestra or conjunctivitis. Am J Vet Res. 1997; 58: 338-342.

24. Kang BT, Park HM. Prevalence of feline herpesvirus 1, feline calicivirus and Chlamydophila felis in clinically normal cats at a Korean animal shelter. Journal of veterinary science. 2008; 9(2): 207-209.

25. Burns RE, Wagner DC, Leutenegger CM, Pesavento PA. Histologic and molecular correlation in shelter cats with acute upper respiratory infection. J Clin Microbiol. 2011; 49: 24542460.

26. Weigler BJ, Guy JS, Nasisse MP, Hancock SI, Sherry B. Effect of a live attenuated int-ranasal vaccine on latency and 
shedding of feline herpesvirus 1 in domestic cats. Arch Virol. 1997; 142 (12): 2389-400.

27. Gaskell R, Dawson S, Radford A, Thiry E. Feline Herpesvirus, Veterinary Research. 2007; 38: 337-354. 